\title{
PEMODELAN DAN PERAMALAN INDEKS HARGA KONSUMEN (IHK) KOTA SAMPIT DENGAN SEASONAL ARIMA (SARIMA)
}

\author{
Agustina Elisa Dyah Purwandari \\ Badan Pusat Statistik (BPS), Kotawaringin Barat \\ email: agustina.purwandari@bps.go.id
}

\begin{abstract}
Sampit is one of 82 cities in Indonesia which calculate inflation. Inflation is an increase of prices on goods and services in a region. Government's control is very important because inflation relates to the real income, the exchange rate, import exports, and so on. Inflation is based on the Consumer Price Index (CPI). Because of CPI is a monthly data prices, it is highly influenced by seasonal factors. Therefore, CPI data modelling is needed because it helps the government to make appropriate policies. Method that can be used for time series data with seasonal influences is Seasonal Autoregressive Integrated Moving Average (SARIMA). The results of the study show that the right model for Sampit's CPI is SARIMA with the order $p=1, d=1, P=1, D=1, Q=1, s=12$. It is the best model that can built and be used for forecasting because with 95 percent of confidence, the model explains 87.23 percent of data. Forecasting in this research use interval analysis and found that January 2020 may be the highest increase of CPI (inflation) in 2020.
\end{abstract}

Keywords: CPI, Inflation, SARIMA

\section{PENDAHULUAN}

Krisis moneter tahun 1998 menjadikan Indonesia mengalami hyper-inflation. Inflasi yang mencapai 70 persen saat itu membuat fluktuasi nilai tukar rupiah terhadap dollar Amerika Serikat turun dari Rp2.500 menjadi Rp17.000 per USD (Ekbis Sindonews, 2019). Krisis moneter saat itu menjadi krisis multidimensi karena berpengaruh ke krisis sosial dan politik. Dampak yang krusial membuat inflasi sangat penting diperhatikan pemerintah karena berhubungan dengan banyak sektor ekonomi, seperti pendapatan riil, nilai tukar rupiah, ekspor impor, penentuan Upah Minimum Regional (UMR), dan sebagainya. Inflasi diartikan sebagai kenaikan harga komoditas yang terjadi secara umum pada suatu wilayah di waktu tertentu. Pada umumnya, inflasi yang cukup tinggi terjadi pada periode tertentu, seperti hari raya dan momen awal-akhir tahun.

Inflasi bulanan yang dikeluarkan oleh Badan Pusat Statistik (BPS) dihitung dari Indeks Harga Konsumen (IHK) yang menggunakan data dua periode, yaitu data bulan berjalan dan data periode sebelumnya. Pemodelan yang menggunakan data bulan berjalan dengan data masa lalunya (data lag) adalah Autoregressive Integrated Moving Average (ARIMA). Data IHK cenderung memiliki faktor musiman karena harga komoditas setiap tahunnya memiliki pola naik-turun yang hampir sama ketika hari raya. Pemodelan ARIMA kurang cocok untuk data deret waktu yang dipengaruhi oleh musiman (Istiqomah, 2015). Oleh sebab itu, ARIMA yang dimodifikasi untuk mengatasi pengaruh musiman adalah Seasonal Autoregressive Integrated Moving Average (SARIMA). 
Pemodelan Dan Peramalan Indeks Harga Konsumen (IHK) Kota Sampit Dengan Seasonal Arima (SARIMA)

Agustina Elisa Dyah Purwandari

Kota Sampit merupakan salah satu dari 82 kota di Indonesia yang menghitung IHK. Bersama dengan Kota Palangkaraya, kedua kota ini membangun inflasi Kalimantan Tengah. Tujuan dilakukannya penelitian ini adalah untuk memodelkan dan meramalkan IHK Kota Sampit. Pemodelan dilakukan menggunakan metode SARIMA karena diduga ada pengaruh musiman terhadap data IHK Kota Sampit. Sementara itu, peramalan dilakukan menggunakan model terbaik yang terbentuk. Secara umum, hasil penelitian ini bisa digunakan sebagai masukan bagi pemerintah dalam menyusun kebijakan yang tepat. Manfaat yang diperoleh tentunya akan mendapatkan model yang akurat dan bisa mendekati IHK riil Kota Sampit, serta menjadi deteksi dini terhadap kemungkinan lonjakan harga yang terlalu tinggi. Harapannya perubahan IHK bisa senantiasa stabil atau tidak terlalu bergejolak.

\section{KAJIAN TEORI}

\section{INFLASI}

Inflasi menurut BPS adalah kecenderungan naiknya harga barang dan jasa secara umum yang terjadi secara terus menerus. Inflasi merupakan salah satu indikator ekonomi yang penting karena naiknya harga barang dan jasa secara umum bisa menyebabkan pendapatan riil masyarakat menurun. Turunnya pendapatan riil masyarakat menyebabkan ekonomi menjadi lesu karena perputaran ekonomi menjadi tidak optimal.

\section{INDEKS HARGA KONSUMEN (IHK)}

Perhitungan inflasi berasal dari perhitungan nilai Indeks Harga Konsumen (IHK). Menurut konsep BPS, IHK merupakan indeks yang menghitung rata-rata perubahan harga dari suatu paket barang dan jasa yang dikonsumsi oleh rumah tangga dalam kurun waktu tertentu. IHK dihitung dari pendataan harga pada Survei Harga Konsumen (SHK) yang dilakukan secara periodik. Perubahan IHK yang meningkat dari periode sebelumnya menggambarkan kenaikan harga barang dan jasa (inflasi). Sebaliknya, penurunan IHK menggambarkan ekonomi yang mengalami deflasi.

Penghitungan IHK saat ini menggunakan tahun dasar 2012=100. Sedangkan inflasi nasional saat ini mencakup perhitungan 82 kota inflasi di seluruh Indonesia. Penghitungan IHK menggunakan rumus Laspeyers yang dimodifikasi, yaitu

$$
I_{n}=\frac{\sum_{i=1}^{k} \frac{P_{n i}}{P_{(n-1) i}} P_{(n-1) i} Q_{o i}}{\sum_{i=1}^{k} P_{o i} Q_{o i}} \times 100
$$

dengan

$I_{n} \quad:$ Indeks periode ke-n

$P_{n i} \quad:$ Harga jenis barang i, periode ke-n

$P_{(n-1) i} \quad$ : Harga jenis barang i, periode ke $(n-1)$

$P_{(n-1) i} Q_{o i}:$ Nilai konsumsi jenis barang i, periode ke $(n-1)$

$P_{o i} Q_{o i} \quad$ : Nilai konsumsi jenis barang i, pada tahun dasar

$k \quad$ : Jumlah jenis barang paket komoditas

\section{ARIMA}

ARIMA merupakan model deret waktu (time series) yang berasal dari pengembangan ARMA. ARIMA terdiri dari model Autoregressive (AR) yang menggunakan hubungan data 
dengan data masa lalu (data lag). Montgomery, et al (2008) dalam bukunya menjelaskan bahwa model $\mathrm{AR}(\mathrm{p})$ mengikuti persamaan umum model sebagai berikut

$$
y_{t}=\delta+\emptyset_{1} y_{t-1}+\emptyset_{2} y_{t-2}+\cdots+\emptyset_{P} y_{t-P}+\varepsilon_{P}
$$

yang mana $\varepsilon_{P}$ mengikuti white noise (berdistribusi normal dengan rata-rata 0 dan varians $\sigma^{2}$ ) dan tidak berkorelasi dengan $y_{s}$ untuk setiap $s<t$.

Integrated (I) merupakan proses differencing untuk menjadikan data dari tidak stasioner menjadi data yang stasioner. Stasioner adalah kondisi data dengan rata-rata dan variansi yang konstan sepanjang waktu.

Sedangkan model Moving Average (MA) menggunakan hubungan data dengan residual yang diaplikasikan pada data masa lalu. Persamaan umum model MA(q) mengikuti

$$
y_{t}=\varepsilon_{t}-\theta_{1} \varepsilon_{t-1}-\cdots-\theta_{q} \varepsilon_{t-q}
$$

dengan $\theta_{1}, \ldots, \theta_{q}$ adalah koefisien eror masa lalu. Untuk mendapatkan nilai $\mathrm{p}$ dan $\mathrm{q}$ bisa dilakukan dengan mengamati pola korelogram Autocorellation (AC) dan Partial Corellation (PAC), yaitu dengan mengamati garis bar yang melewati garis putus-putus.

\section{SARIMA}

Pemodelan ARIMA kurang cocok digunakan pada data runtut waktu (time series) dengan pola musiman. Oleh karena itu, SARIMA merupakan model ARIMA yang dimodifikasi dengan mempertimbangkan faktor musiman. Persamaan umum model $\operatorname{SARIMA}(p, d, q)(P, D, Q) s$ dalam Montgomery, et al (2008) adalah sebagai berikut

$$
\Phi^{*}\left(B^{S}\right) \Phi(B)(1-B)^{d}\left(1-B^{S}\right)^{D} y_{t}=\delta+\Theta^{*}\left(B^{S}\right) \Theta(B) \varepsilon_{t}
$$

$$
\begin{array}{ll}
\text { dengan } & \\
\Phi(B) & \text { : AR non seasonal } \\
\Phi^{*}\left(B^{S}\right) & \text { : AR seasonal } \\
(1-B)^{d} & \text { : Differencing non seasonal } \\
\left(1-B^{S}\right)^{D} & \text { : Differencing seasonal } \\
\Theta(B) & \text { : MA non seasonal } \\
\Theta^{*}\left(B^{S}\right) & \text { : MA seasonal }
\end{array}
$$

Penentuan nilai $\mathrm{p}$ dan $\mathrm{q}$ bisa dilakukan melalui pola korelogram Autocorellation (AC) dan Partial Corellation (PAC).

\section{PENELITIAN TERDAHULU}

Penelitian terkait IHK dengan metode SARIMA pernah dilakukan oleh Wibowo, Ananto (2018) terhadap Kota Palangkaraya. Data IHK yang digunakan adalah data bulan Januari 2014 hingga Desember 2017. Hasil penelitian menemukan bahwa dengan tingkat kepercayaan 95 persen, pemodelan IHK Kota Palangkaraya mengikuti model SARIMA $(1,1,0)(3,1,2)^{6}$ dan mampu menjelaskan 84,67 persen IHK Kota Palangkaraya.

Peramalan IHK juga dilakukan oleh Lubis, et al (2017) yang menggunakan perbandingan metode SARIMA dan Singular Spectral Analysisi (SSA). Hasil penelitiannya menemukan bahwa SARIMA $(0,1,1)(0,1,1)^{6}$ merupakan model paling tepat dalam memprediksi IHK Kota Padangsidempuan pada Januari 2008 sampai dengan November 2016.

Ukhra, Anisa (2014) dalam penelitiannya menemukan metode SARIMA dengan ordo SARIMA $(1,1,0)(0,1,0)^{12}$ merupakan model dengan eror terkecil. Metode SARIMA tersebut dipakai untuk meramalkan data jumlah penumpang suatu maskapai dari tahun 1949 -1959. 
Pemodelan Dan Peramalan Indeks Harga Konsumen (IHK) Kota Sampit Dengan Seasonal Arima (SARIMA)

Agustina Elisa Dyah Purwandari

Istiqomah, Nalar (2015) menemukan bahwa model SARIMA $(1,0,0,)(0,1,12)^{12}$ menjadi model terbaik dalam pemodelan kemunculan titik panas di Provinsi Riau. Pemodelan tersebut dilakukan menggunakan data 2001 sampai dengan 2012.

\section{METODE PENELITIAN}

Data IHK dalam penelitian ini menggunakan data sekunder yang bersumber dari BPS Kotawaringin Timur. Kota Sampit merupakan pusat Kabupaten Kotawaringin Timur. Periode data IHK Kota Sampit yang digunakan dimulai dari bulan Januari tahun 2015 hingga September tahun 2019. Dikarenakan data IHK merupakan data bulanan, maka terdapat 57 observasi. Sedangkan program pengolahan data yang digunakan adalah Eviews 7.

Kerangka berpikir pada penelitian ini seperti pada Gambar 1. Sekalipun diketahui data IHK dipengaruhi oleh faktor musiman, tetapi harus diuji ulang ada tidaknya pola seasonal. Ketika terbukti ada pola musiman, maka metode SARIMA akan digunakan. Sebaliknya, jika tidak ada faktor musiman, metode yang digunakan adalah ARIMA. Dari kandidat model yang bisa dibentuk, dilakukan seleksi pemilihan model terbaik dengan berbagai kriteria. Setelah model terbaik didapatkan, langkah selanjutnya adalah melakukan evaluasi terhadap model terbaik dengan mengecek pemenuhan asumsi. Langkah terakhir adalah melakukan peramalan menggunakan model terbaik yang terbentuk.

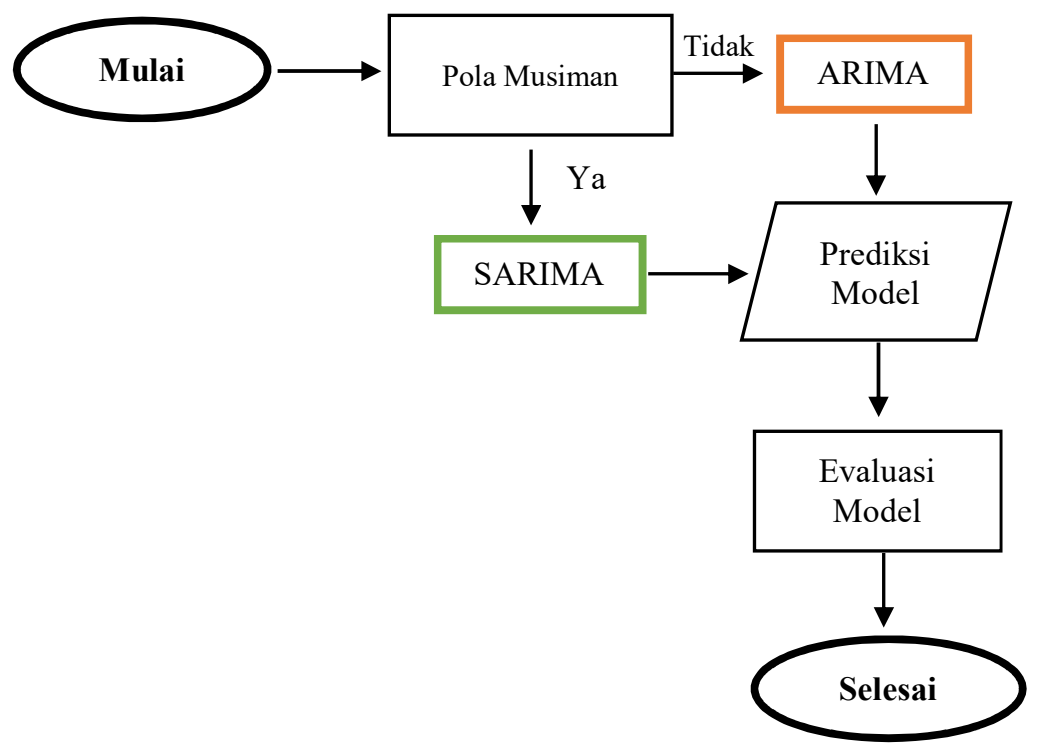

Gambar 1. Kerangka Berpikir

Tahapan analisis yang digunakan dalam penelitian ini seperti yang ada pada gambar 2 . Tahapan tersebut meliputi 3 tahap besar, yaitu identifikasi, estimasi pengujian, serta tahap aplikasi.

Tahap identifikasi model meliputi proses pengecekan kestasioneran data. Jika data sudah stasioner, langkah selanjutnya adalah melakukan penentuan ordo AR dan MA melalui bar korelogram.

Tahap kedua (estimasi dan pengujian) melalui pemilihan model yang akan saling diperbandingkan dari semua kemungkinan model yang bisa dibentuk. Model terbaik akan 
digunakan untuk menduga nilai parameter. Langkah selanjutnya adalah diagnosa model terbaik melalui pemeriksaan asumsi-asumsi yang harus dipenuhi oleh model terbaik.

Tahap ketiga adalah aplikasi yang merupakan peramalan atau forecasting terhadap data periode selanjutnya. Peramalan ini dilakukan dengan menggunakan model terbaik yang didapatkan.

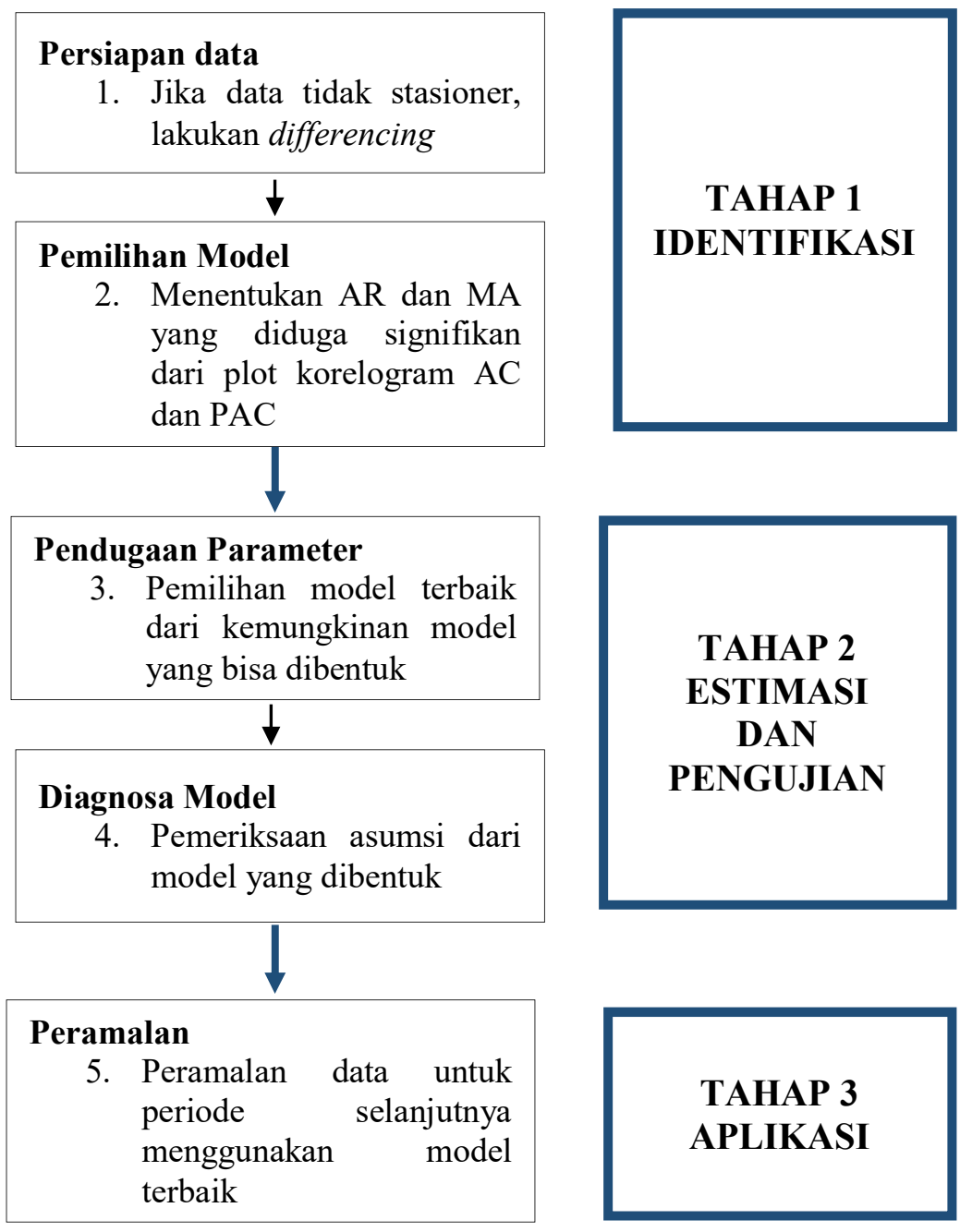

Gambar 2. Tahapan Analisis

\section{HASIL DAN PEMBAHASAN}

Tahap pertama analisis yang dilakukan adalah identifikasi data. Pola pergerakan data IHK yang akan digunakan terdapat pada Grafik 1. Secara visual, terlihat grafik batang yang tingginya berpola naik turun dan tidak menumpuk hanya di salah satu sisi kanan atau kiri saja. Artinya, data IHK berdistribusi normal. Hal ini bisa dibuktikan dengan uji Jarque Berra yang juga menerima hipotesis nol, artinya dengan tingkat kepercayaan 95 persen, dapat disimpulkan data IHK Kota Sampit berdistribusi normal. 
Pemodelan Dan Peramalan Indeks Harga Konsumen (IHK) Kota Sampit Dengan Seasonal Arima (SARIMA)

Agustina Elisa Dyah Purwandari

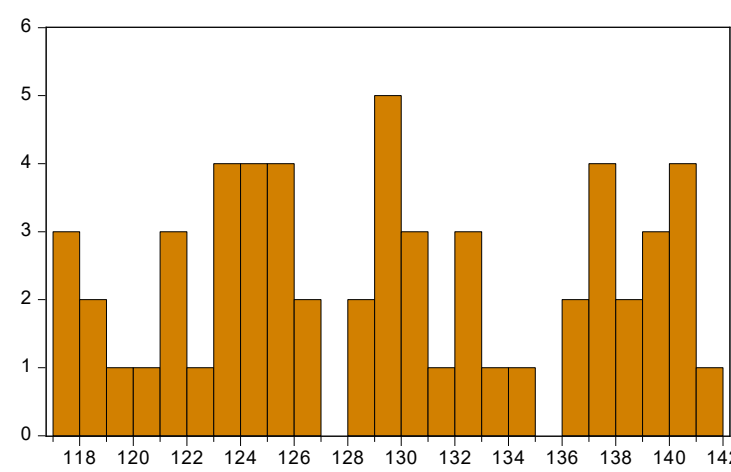

Series: IHKSAMPIT

Sample 2015M01 2019M09

Observations 57

Mean $\quad 129.4704$

Median $\quad 129.8200$

Maximum $\quad 141.1600$

Minimum $\quad 117.1100$

Std. Dev. $\quad 7.229202$

Skewness $\quad 0.067219$

Kurtosis $\quad 1.840940$

Jarque-Bera 3.233549

Probability 0.198538

Grafik 1. Histogram data IHK Kota Sampit

IHKSAMPIT

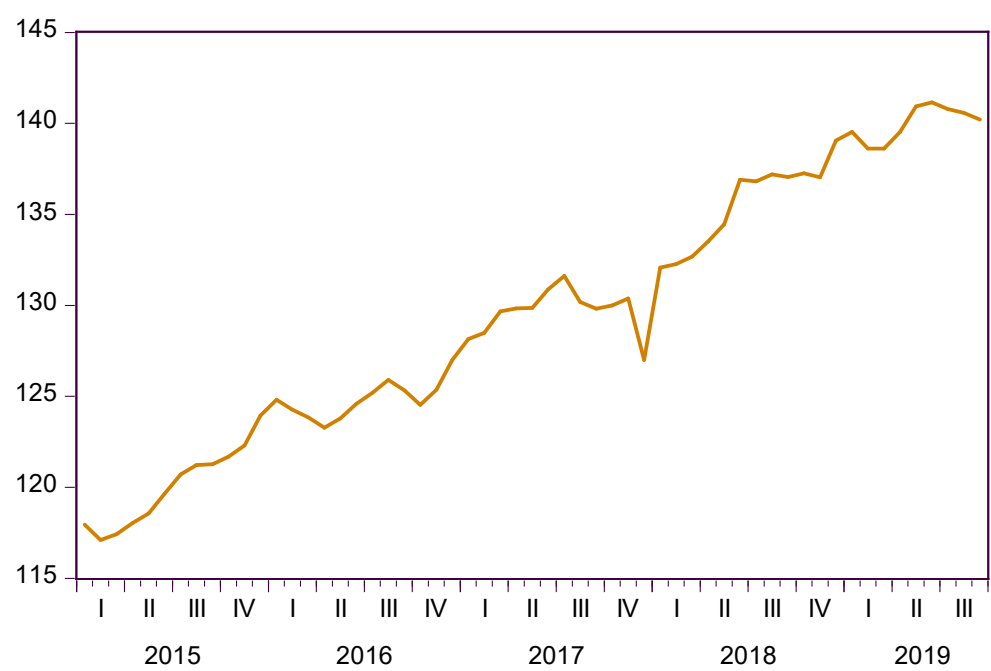

Grafik 2. Pola IHK Kota Sampit Orde ke-0

Pergerakan data runtut waktu lebih tepat jika diolah dalam bentuk grafik line seperti yang terlihat di Grafik 2. Pola data IHK Kota Sampit terlihat bergerak naik turun yang berulangulang dan membentuk pola. Dapat diartikan pola ini sebagai pola musiman yang berulang setiap tahun $(s=12)$. Selain berpola naik turun, data juga terlihat mempunyai tren peningkatan dari tahun ke tahun.

Dikarenakan terbukti data mengandung tren, maka data pada orde nol diduga sudah tidak stasioner. Hal ini dibuktikan dengan uji Augmented Dickey Fuller (ADF) bahwa dengan tingkat kepercayaan 95 persen, data masih mengandung unit root (menerima hipotesis nol) karena $p$ value $(0,8662)$ lebih besar daripada tingkat signifikansi. Supaya data menjadi stasioner terhadap rata-rata dan varians, langkah yang perlu dilakukan adalah mendiferensiasinya (differencing).

Setelah melakukan diferensiasi orde pertama dan menghilangkan pola musiman $(s=12)$, data sudah menjadi stasioner seperti yang terlihat pada grafik 3. Kedua grafik bergerak pada 
rerataan dan variasi data yang sudah konstan sepanjang waktu. Pola tren sudah tidak terlihat lagi, artinya tidak ada peningkatan data seiring peningkatan waktu.

Pada grafik 3, data pada tahun pertama untuk grafik merah menjadi kosong karena proses diferensiasi dalam pembentukan stasioneritas memanfaatkan faktor musiman yang berulang setiap 12 bulan sekali $(s=12)$. Sedangkan untuk data yang tidak dipengaruhi pola musiman (grafik biru), menunjukkan adanya pengosongan di bulan pertama tahun pertama penelitian karena proses differensiasi yang memanfaatkan selisih data dua periode. Kestasioneran data hasil diferensiasi orde pertama teruji pada pada uji ADF (tabel 1). Dengan tingkat signifikansi 95 persen, dapat disimpulkan data sudah stasioner (tidak mengandung unit root).

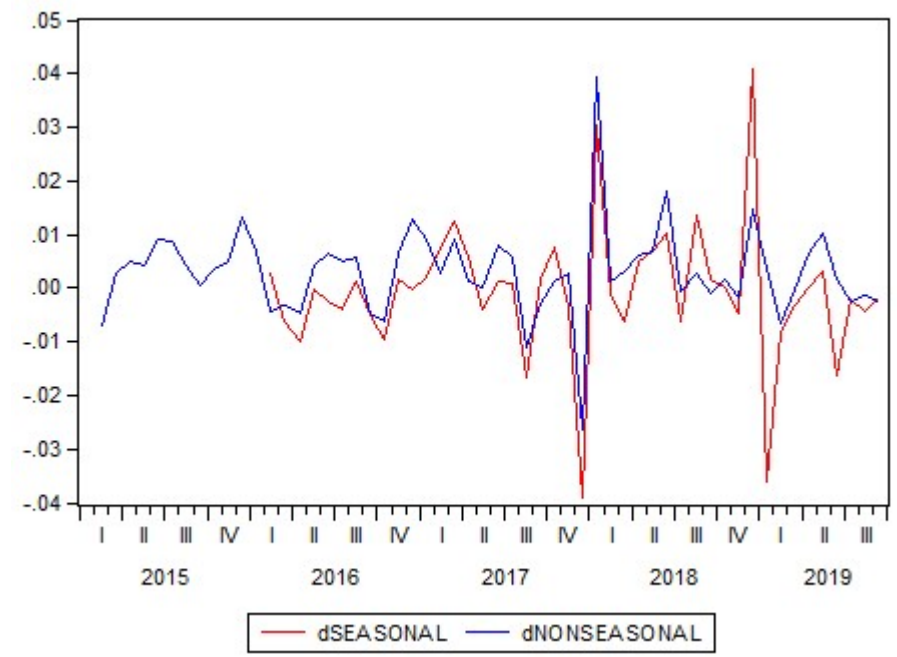

Grafik 3. Pola IHK Kota Sampit Orde ke-1 (Diferensiasi Pertama)

Tabel 1. Uji ADF Orde ke-1

Null Hypothesis: D(IHKSAMPIT) has a unit root

Exogenous: Constant

Lag Length: 0 (Automatic - based on SIC, maxlag=10)

\begin{tabular}{lccc}
\hline \hline & t-Statistic & Prob. ${ }^{*}$ \\
\hline \hline Augmented Dickey-Fuller test statistic & -8.810270 & \multirow{2}{*}{0.0000} \\
\hline Test critical values: & $1 \%$ level & -3.555023 & \\
& $5 \%$ level & -2.915522 & \\
& $10 \%$ level & -2.595565 & \\
\hline
\end{tabular}

*MacKinnon (1996) one-sided p-values. 
Pemodelan Dan Peramalan Indeks Harga Konsumen (IHK) Kota Sampit Dengan Seasonal Arima (SARIMA)

Agustina Elisa Dyah Purwandari

Dikarenakan data sudah stasioner, langkah selanjutnya adalah penentuan lag pada Autocorrelation (AC) dan Partial Autocorrelation (PAC) yang signifikan menggunakan Grafik 4. Estimasi dimulai dengan penentuan lag yang melewati garis putus-putus.

\begin{tabular}{|c|c|c|c|c|c|c|c|c|}
\hline \multicolumn{2}{|c|}{ Autocorrelation } & \multicolumn{2}{|c|}{ Partial Correlation } & & $\mathrm{AC}$ & PAC & Q-Stat & Prob \\
\hline$\square$ & 1 & $\square$ & I & & $1-0.326$ & -0.326 & 5.0051 & 0.025 \\
\hline 10 & 1 & $1 \square$ & 1 & & $2-0.085$ & -0.214 & 5.3493 & 0.069 \\
\hline 1 & 01 & 1 & 1 & 3 & 30.103 & -0.001 & 5.8681 & 0.118 \\
\hline 1 & • & 1 & ا & 4 & $4 \quad 0.179$ & 0.236 & 7.4853 & 0.112 \\
\hline 1 다 & 1 & 1 & I & & $5-0.143$ & 0.037 & 8.5428 & 0.129 \\
\hline 10 & 1 & 10 & 1 & 6 & $5-0.102$ & -0.133 & 9.0999 & 0.168 \\
\hline & 曰 & 1 & 1 & 7 & 0.155 & 0.008 & 10.407 & 0.167 \\
\hline 1 다 & 1 & 1 든 & 1 & & -0.145 & -0.162 & 11.582 & 0.171 \\
\hline 1 & 1 & '口 & I & & -0.168 & -0.254 & 13.214 & 0.153 \\
\hline 1 & 1 & 1맘 & 1 & 10 & -0.022 & -0.232 & 13.242 & 0.210 \\
\hline 1 & $\square$ & 1 & 1 & 11 & 0.246 & 0.157 & 16.967 & 0.109 \\
\hline$\square$ & 1 & $\square$ & 1 & 12 & $2-0.459$ & -0.317 & 30.288 & 0.003 \\
\hline 1 & 1 & 1 & 1 & 13 & $\begin{array}{ll}3 & 0.125\end{array}$ & -0.052 & 31.307 & 0.003 \\
\hline & 口 & 1 & 1 & 14 & 40.171 & 0.110 & 33.290 & 0.003 \\
\hline 1 & 1 & 1 & ] 1 & 15 & 50.000 & 0.109 & 33.290 & 0.004 \\
\hline & 1 & 1 & 1 & 16 & -0.098 & 0.101 & 33.980 & 0.005 \\
\hline 1 & 1 & I & I & 17 & $7 \quad 0.067$ & -0.017 & 34.312 & 0.008 \\
\hline 1 & 1 & 10 & 1 & 18 & 30.095 & -0.169 & 35.017 & 0.009 \\
\hline 1 & 1 & 1 & 1 & 19 & -0.039 & -0.029 & 35.139 & 0.013 \\
\hline 1 & 1 & 1 & 1 & 20 & 0.085 & 0.094 & 35.750 & 0.016 \\
\hline 1 & 1 & 1 & 1 & 21 & $1 \quad 0.029$ & 0.002 & 35.822 & 0.023 \\
\hline 10 & 1 & 10 & 1 & 22 & -0.052 & -0.110 & 36.069 & 0.030 \\
\hline 1 & I & 1 & 1 & 23 & $3-0.038$ & 0.143 & 36.212 & 0.039 \\
\hline 1 & 1 & । & 1 & 24 & $4-0.026$ & -0.236 & 36.278 & 0.052 \\
\hline 1 & 1 & 10 & 1 & 25 & 50.004 & -0.099 & 36.280 & 0.067 \\
\hline 15 & 1 & 1 & 1 & 26 & -0.092 & 0.002 & 37.222 & 0.071 \\
\hline 1 & 1 & I & 1 & 27 & $7-0.007$ & -0.014 & 37.227 & 0.091 \\
\hline 1 & 1 & 1 & 1 & 28 & 30.014 & 0.031 & 37.250 & 0.113 \\
\hline 1 & 1 & I & 1 & 29 & -0.052 & 0.011 & 37.615 & 0.131 \\
\hline 1 & 1 & 10 & 1 & 30 & 0.001 & -0.085 & 37.615 & 0.160 \\
\hline 1 & 1 & 1 & 1 & 31 & 0.008 & -0.041 & 37.624 & 0.192 \\
\hline 1 & 1 & 1 & 1 & 32 & $2-0.033$ & -0.017 & 37.803 & 0.221 \\
\hline
\end{tabular}

Grafik 4. Korelogram IHK Orde ke-1

Pada Autocorrelation (AC), bar pada lag 1 melewati garis putus-putus dan terjadi cut off setelahnya. Oleh sebab itu, nilai Moving Average (MA) diduga 1. Sementara untuk Partial Correlation (PAC), bar pada lag 1 juga melewati garis putus-putus dan juga terjadi cut off setelahnya. Oleh sebab itu, nilai AR diduga bernilai 1. Dikarenakan data non musiman juga mengalami diferensiasi orde pertama, maka identifikasi untuk ordo non musiman bernilai $p=1$, $q=1, d=1$.

Sementara untuk komponen musiman, bar AC maupun PAC keduanya sama-sama memiliki lag yang cut off melebihi angka 12 . Dikarenakan data musiman juga mengalami diferensiasi orde pertama, diduga ordo musiman bernilai $P=1, Q=1, D=1$, dengan $s=12$.

Model tentatif yang dapat dibangun dari model SARIMA dengan ordo yang sudah teridentifikasi terdapat pada Tabel 2. Dengan menyatukan ordo non musiman dan ordo musiman, didapatkan 9 model yang kemudian dilakukan perbandingan antar modelnya. 
Tabel 2. Identifikasi Ordo Model SARIMA

\begin{tabular}{|c|c|c|}
\hline Ordo non musiman & Ordo musiman & Model SARIMA \\
\hline (1) & (2) & (3) \\
\hline \multirow[t]{3}{*}{ IMA(1) } & $\operatorname{IMA}(1)$ & $\operatorname{ARIMA}(0,1,1)(0,1,1)^{12}$ \\
\hline & ARI(1) & $\operatorname{ARIMA}(0,1,1)(1,1,0)^{12}$ \\
\hline & $\operatorname{ARIMA}(1,1,1)$ & $\operatorname{ARIMA}(0,1,1)(1,1,1)^{12}$ \\
\hline \multirow[t]{3}{*}{ ARI(1) } & $\operatorname{IMA}(1)$ & $\operatorname{ARIMA}(1,1,0)(0,1,1)^{12}$ \\
\hline & ARI(1) & $\operatorname{ARIMA}(1,1,0)(1,1,0)^{12}$ \\
\hline & $\operatorname{ARIMA}(1,1,1)$ & $\operatorname{ARIMA}(1,1,0)(1,1,1)^{12}$ \\
\hline \multirow[t]{3}{*}{$\operatorname{ARIMA}(1,1,1)$} & $\operatorname{IMA}(1)$ & $\operatorname{ARIMA}(1,1,1)(0,1,1)^{12}$ \\
\hline & ARI(1) & $\operatorname{ARIMA}(1,1,1)(1,1,0)^{12}$ \\
\hline & $\operatorname{ARIMA}(1,1,1)$ & $\operatorname{ARIMA}(1,1,1)(1,1,1)^{12}$ \\
\hline
\end{tabular}

Tahapan analisis kedua adalah menggunakan masing-masing model yang ada pada Tabel 2 ke dalam proses estimasi. Hasil pengolahan didapatkan data seperti pada Tabel 3. Dari semua model yang diujicobakan, didapatkan model terbaik adalah model dengan ARIMA $(1,1,0)(1,1,1)^{12}$ karena semua variabel signifikan. Selain itu, model memiliki nilai $\mathrm{R}^{2}$ Adj terbesar $(87,23$ persen) dan nilai SSR yang terbukti paling kecil dibandingkan model lainnya $(0,000916)$.

Tabel 3. Pendugaan Parameter Model SARIMA

\begin{tabular}{ccc}
\hline Model & Signifikansi Model & $\mathrm{R}^{2}$ Adjusted \\
\hline$(1)$ & $(2)$ & $(3)$ \\
\hline Model 1 & YA & 0.6372 \\
\hline Model 2 & YA & 0.4243 \\
\hline$\vdots$ & & \\
\hline Model 9 & TIDAK & - \\
\hline
\end{tabular}

Diagnosa model melalui pengecekan asumsi menjadi tahap selanjutnya. Hal ini perlu dilakukan untuk memastikan model terbaik yang terbentuk memang baik untuk melakukan peramalan atau forecasting. Pemenuhan terhadap asumsi autokorelasi dilakukan dengan uji Breusch-Godfrey Serial. Hasilnya dengan tingkat signifikansi 5 persen, Ho tidak ditolak. Artinya eror tidak berautokorelasi.

Pengecekan terhadap eror juga perlu dilakukan melalui melalui uji Jarque Berra. Hasilnya Ho juga tidak ditolak. Dapat disimpulkan dengan tingkat kepercayaan 95 persen, eror berdistribusi normal.

Tabel 4. Hasil Estimasi Parameter Model SARIMA

\begin{tabular}{ccc}
\hline Variabel & Koefisien & Std.Eror \\
\hline$(1)$ & $(2)$ & $(3)$ \\
\hline C & 0,0407 & 0,0023 \\
\hline AR(1) & 0,7096 & 0,1236 \\
\hline SAR(12) & $-0,9611$ & 0,1445 \\
\hline SMA(12) & $-0,9301$ & 0,0408 \\
\hline
\end{tabular}


Pemodelan Dan Peramalan Indeks Harga Konsumen (IHK) Kota Sampit Dengan Seasonal Arima (SARIMA)

Agustina Elisa Dyah Purwandari

Berdasarkan Tabel 4, dapat ditulis persamaan model mengikuti persamaan (4), yaitu

$$
\Phi^{*}\left(B^{S}\right) \Phi(B)(1-B)^{d}\left(1-B^{S}\right)^{D} y_{t}=\delta+\Theta^{*}\left(B^{S}\right) \Theta(B) \varepsilon_{t}
$$

dengan memasukkan estimasi parameter model yang didapatkan, maka

$$
\left(1-0,9611 B^{12}\right)(1-0,7096 B)\left(1-B^{12}\right)(1-B) y_{t}=0,0407+\left(1-0,9301 B^{12}\right) \varepsilon_{t}
$$

atau bisa ditulis dengan

$$
\begin{aligned}
y_{t}= & 0,0407+0,7096 B+0,9611 B^{12}+0,3181 B^{13}+0,7096 B^{14}+0,9611 \\
& 0,6891 B^{26}+\varepsilon_{t}-0,9301 \varepsilon_{t-12} \\
y_{t}= & 0,0407+0,7096 X_{t-1}+0,9611 X_{t-12}+0,3181 X_{t-13}+0,7096 X_{t-14} \\
& +0,9611 X_{t-25}+0,6891 X_{t-2}+\varepsilon_{t}-0,9301 \varepsilon_{t-12}
\end{aligned}
$$

sehingga persamaan estimasi model IHK Kota Sampit mengikuti persamaan (7).

Sebelum melakukan peramalan, perlu dicek ulang apakah model yang terbentuk sudah powerfull. Perbandingan antara data riil aktual dengan data yang dimodelkan diperlukan untuk mengetahui seberapa tepat model terbaik mampu mendekati data aktual (riil). Perbandingan ini terdapat pada Grafik 5. Grafik warna hitam adalah data aktual IHK dan grafik warna hijau adalah data hasil pemodelan. Terlihat kedua garis saling berdekatan. Artinya, model yang dihasilkan mampu meramalkan data IHK dengan kondisi yang tidak terlalu berbeda (mendekati). Oleh sebab itu, model yang dihasilkan merupakan model yang sangat powerfull.

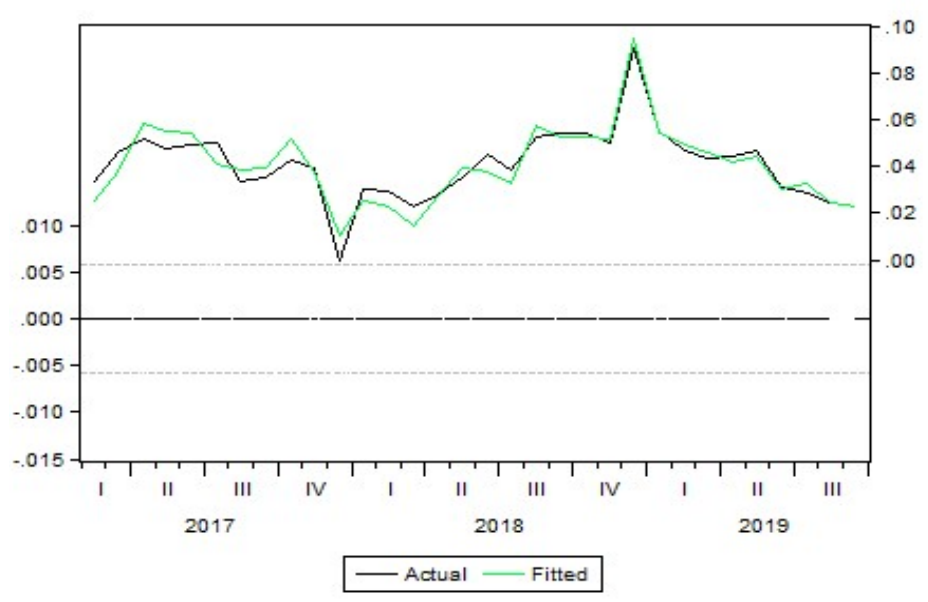

Grafik 5. Perbandingan Data Aktual dengan Data Ramalan

Setelah semua asumsi terpenuhi dan model terbukti sangat powerfull, tahap analisis terakhir adalah aplikasi. Tahap ini meramalkan data periode berikutnya menggunakan model terbaik yang terbentuk. Dalam penelitian ini, model terbaik adalah ARIMA $(1,1,0)(1,1,1)^{12}$. 


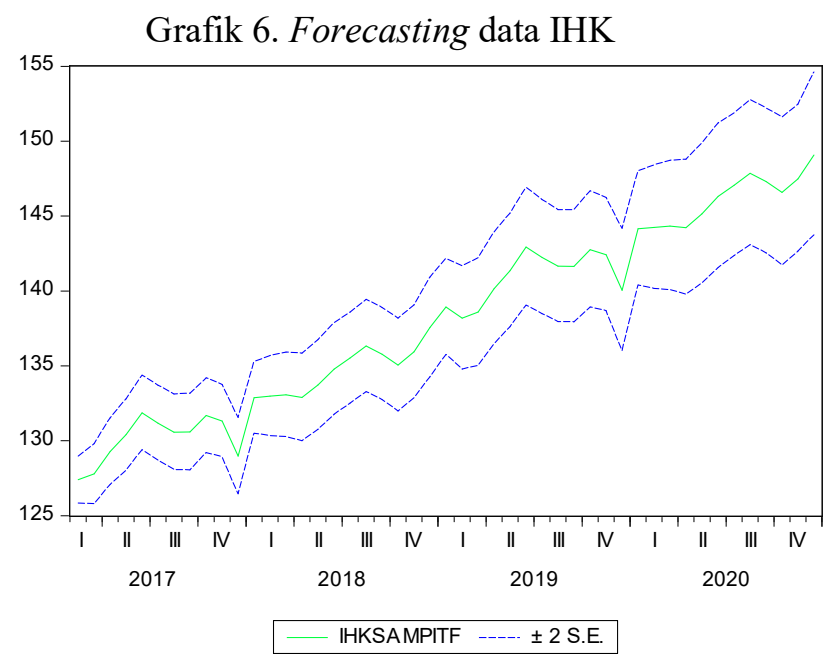

Tabel 5. Forecasting data IHK

\begin{tabular}{lcc}
\multirow{2}{*}{\multicolumn{1}{c}{ Bulan }} & \multicolumn{2}{c}{ IHK Hasil Ramalan } \\
\cline { 2 - 3 } & Batas Bawah & Batas Atas \\
\hline Oktober 2019 & $(2)$ & $(3)$ \\
\hline November 2019 & 138,9 & 146,7 \\
\hline Desember 2019 & 138,7 & 146,2 \\
\hline Januari 2020 & 136,0 & 144,2 \\
\hline Februari 2020 & 140,4 & 148,0 \\
\hline Maret 2020 & 140,2 & 148,4 \\
\hline April 2020 & 140,1 & 148,7 \\
\hline Mei 2020 & 139,8 & 148,8 \\
\hline Juni 2020 & 140,5 & 149,9 \\
\hline Juli 2020 & 141,6 & 151,2 \\
\hline Agustus 2020 & 142,4 & 151,9 \\
\hline September 2020 & 143,1 & 152,8 \\
\hline Oktober 2020 & 142,5 & 152,2 \\
\hline November 2020 & 141,7 & 151,6 \\
\hline Desember 2020 & 142,7 & 152,5 \\
\hline
\end{tabular}

Dengan tingkat kepercayaan 95 persen, IHK Kota Sampit dari Oktober 2019 hingga Desember 2020 diramalkan berada pada rentang seperti pada Tabel 5. Berdasarkan Grafik 6, peningkatan IHK terbesar terjadi pada bulan Januari 2020. Artinya, pada bulan Januari 2020 yang dibandingkan terhadap Desember 2019, dimungkinkan terjadi inflasi tertinggi selama tahun 2020 mendatang.

\section{KESIMPULAN}

Model SARIMA $(1,1,0)(1,1,1)^{12}$ merupakan model terbaik untuk meramalkan data IHK Kota Sampit. Dengan kepercayaan 95 persen, disimpulkan model tersebut dapat 
Pemodelan Dan Peramalan Indeks Harga Konsumen (IHK) Kota Sampit Dengan Seasonal Arima (SARIMA)

Agustina Elisa Dyah Purwandari

mendeskripsikan 87,23 persen data IHK Kota Sampit. Bukan hanya menjadi model terbaik, model tersebut juga sangat powerfull dalam melakukan ramalan karena mendekati data aktual. Hasil peramalan menemukan bahwa pada bulan Januari 2020, diduga terjadi peningkatan IHK (inflasi) terbesar selama tahun 2020.

\section{REFERENSI}

Anggraeni, Rina. 2019. BI Ceritakan Penyebab Krisis Ekonomi 1998. Edisi Rabu, 26 Juni 2019. Diakses pada https://ekbis.sindonews.com/read/1415039/33/bi-ceritakanpenyebab-krisis-ekonomi-1998-1561553591 pada 15 Oktober 2019 pukul 14.00 WIB.

Istiqomah, Nalar. 2015. Prediksi Kemunculan Titik Panas di Provinsi Riau Menggunakan Seasonal Autoregressive Integrated Moving Average (SARIMA). IPB

Lubis, dkk. 2017. "Peramalan Indeks Harga Konsumen Dengan Metode SSA dan SARIMA", dalam Jurnal Matematika MANTIK Edisi Oktober 2017: Vol 3 No.2

Montgomerry, et al. 2008. Introduction to Time Series Analysis and Forecasting. Amerika: John Wiley \& Sons Inc.

Ukhra, Annisa. 2014. "Pemodelan dan Peramalan Data Deret Waktu Dengan MEtode Seasonal Arima", dalam Jurnal Matematika UNAND Vol.3 No.3 Hal 59-67.

Wibowo, Ananto. 2018. "Model Peramalan Indeks Harga Konsumen Kota Palangka Raya Menggunakan Seasonal ARIMA (SARIMA)", dalam Ejournal Unisba : Jurnal Matematika Vol. 17 No.2, November 2018. 